\title{
Diversity and Abundance of Waterbird Communities in the Jaffna and Kilinochchi Districts: Where do we have to go from here?
}

\author{
G Kandasamy $^{1 *}$, D K Weerakoon ${ }^{2}$, A Sivaruban ${ }^{1}$, H B Jayasiri ${ }^{3}$ \\ ${ }^{1}$ Department of Zoology, Faculty of Science, University of Jaffna, Sri Lanka. \\ ${ }^{2}$ Department of Zoology, University of Colombo, Sri Lanka. \\ ${ }^{3}$ Ocean University of Sri Lanka, Crow Island, Colombo 15, Sri Lanka. \\ *Email:vadhana.gk@gmail.com
}

\begin{abstract}
Wetlands and waterbirds are inseparable elements. The preliminary study was conducted in eight sites, namely Mandaitivu, Mankumban, Kayts, Kavutharimunai, Pallai, Thadduvankoddy, Kapputhu and Nagarkovil in the Jaffna and Kilinochchi Districts of the northern region of Sri Lanka to determine the diversity and abundance of waterbirds. In each site, three counting blocks in length of $500 \mathrm{~m}$ with open width was selected for bird counting. Each block was separated at least by length of $500 \mathrm{~m}$ to avoid double counting. The counting of birds was done once a month from December, 2016 to May, 2017. Eighteen waterbird families were recorded. Phoenicopteridae, Anatidae and Scolopacidae were the dominant families. The presence of critically endangered species such as Spot-billed Duck (Anas poecilorhyncha) suggests the importance of conservation of these habitats. Two-way ANOVA indicated that waterbird families were significantly different among eight sites. The highest species richness was found in Kapputhu (57) and the lowest in Kavutharimunai (26). This study revealed that Mandaitivu, Mankumban, Kayts, Thadduvankoddy and Kapputhu are the excellent places to observe both migrant ducks and flamingos. Likewise Kavutharimunai is good for migrant shorebirds and seabirds by ferry while Nagarkovil and Kapputhu are suitable for viewing both feeding and roosting of waterbirds. On the whole this paper reveals that the northern region of Sri Lanka possess not only the potential of avitourism but also will become the hotspot of future bird researches, especially on waterbirds.
\end{abstract}

Keywords— Jaffna, Kilinochchi, waterbird communities, avitourism, hotspot

\section{INTRODUCTION}

Wetlands and waterbirds are inseparable elements (Grimmett and Inskipp, 2007). According to Ramsar convention, waterbirds have been defined as species of birds that are ecologically dependent upon wetlands (Wetlands International, 2010). Waterbirds inhabit or temporarily use wetlands because of the diversity of microhabitats for feeding, nesting, resting and roosting (Hattori and Mae, 2001). At present, 454 species of birds including 238 breeding resident and 144 regular migrants and 72 vagrants were recorded in Sri Lanka. 23 families of waterbirds (164 species) have been identified in Sri Lanka (Wijesundara et al., 2017).

Wetlands in Sri Lanka are the final destination each year for tens of thousands of migrant birds flying southward along the Central- Asian 'flyway' (Warakagoda and Sirivardana, 2006). Migratory birds that use the Central Asian flyway, use five main entry and exit points to enter Sri Lanka, of which three are located in the Northern Province of Sri Lanka namely, the Jaffna Peninsula, the Adam's Bridge/Mannar region and the Devil's Point (Kotagama and Ratnavira, 2010).

Although bird-related studies have been undertaken in the northern region of Sri Lanka (Kandasamy et al., 2016; Kandasamy et al., 2017a; Kandasamy et al., 2017b; Kandasamy et al., 2017c; Kandasamy et al., 2017d; Kandasamy et al., 2018; Rajkumar and Wijesundara, 2014; Wijesundara et al., 2015;
Wijesundara et al., 2017; Rajkumar and Wijesundara, 2015a; Rajkumar and Wijesundara, 2015b; Wijesundara et al., 2015; Rajkumar and Wijesundara, 2017; Wijesundara and Rajkumar, 2016; Wijesundara et al., 2016; Wijesundara and Rajkumar, 2017; Wijesundara et al., 2018) waterbird communities have not been studied in many areas in the northern region of Sri Lanka as the area was inaccessible for three decades due to the armed conflict. Hence the present study was conducted to document the diversity and abundance of waterbirds in these districts and to find out the possibilities of ecotourism in selected areas in this region.

\section{MATERIALS AND METHODS}

The present study was carried out in eight locations (Figure 1) namely, Mandaitivu in the Island South Divisional secretariat division (DSD ( $\left.9^{0} 37^{\prime} 28^{\prime \prime} \mathrm{N}, 79^{\circ} 59^{\prime} 52^{\prime \prime} \mathrm{E}\right)$, Mankumban in the Island South DSD $\left(9^{0} 38^{\prime} 31^{\prime \prime} \mathrm{N}, 79^{0} 56^{\prime} 28^{\prime \prime} \mathrm{E}\right)$, Kayts in the Island North DSD ( $9^{0} 40^{\prime} 17^{\prime}$ ' N, 79 ${ }^{0} 55^{\prime} 30^{\prime \prime}$ E), Kavutharimunai in the Pooneryn DSD $\left(9^{0} 34^{\prime} 42^{\prime \prime} \mathrm{N}, 80^{\circ} 06^{\prime} 24^{\prime \prime}\right.$ ), Pallai wind farm in the Pachchilappalli DSD $\left(9^{0} 35^{\prime} 59^{\prime \prime} \mathrm{N}, 80^{\circ} 18^{\prime} 60^{\prime \prime} \mathrm{E}\right)$, Thadduvankoddy in the Kandavalai DSD $\left(9^{0} 30^{\prime} 0^{\prime \prime} \mathrm{N}, 80^{\circ} 25^{\prime} 0^{\prime \prime} \mathrm{E}\right)$, Kapputhu in the Vadamaradchi South West DSD $\left(9^{0} 44^{\prime} 09^{\prime \prime} \mathrm{N}\right.$, $80^{\circ} 10^{\prime} 48^{\prime \prime} \mathrm{E}$ ), and Nagarkovil in the Vadamaradchi East DSD ( $9^{0} 36^{\prime} 00^{\prime \prime} \mathrm{N}, 80^{\circ} 17^{\prime} 00^{\prime}$ E).

A line transect was established in each study site, the entire transect belt was divided into three blocks in length of $500 \mathrm{~m}$ with open width. Each block was separated at least by $500 \mathrm{~m}$ 
to avoid double counting as most were open areas. All the waterbirds seen on either side of the transect up to $500 \mathrm{~m}$ were counted during dawn and noon or dusk on alternate months to capture temporal variations by walking along the transect line of each block. Waterbird counting was done by ferry in Kavutharimunai with the help of the Fisheries' Society, Maniththalai, Kavutharimunai. Waterbird species were identified using a standard field guide (Harrison, 2011). Counting blocks were visited once a month from December, 2016 to May, 2017. Then a list of status of waterbirds was prepared following Harrison, 2011 and Wijesundara et al., 2017.

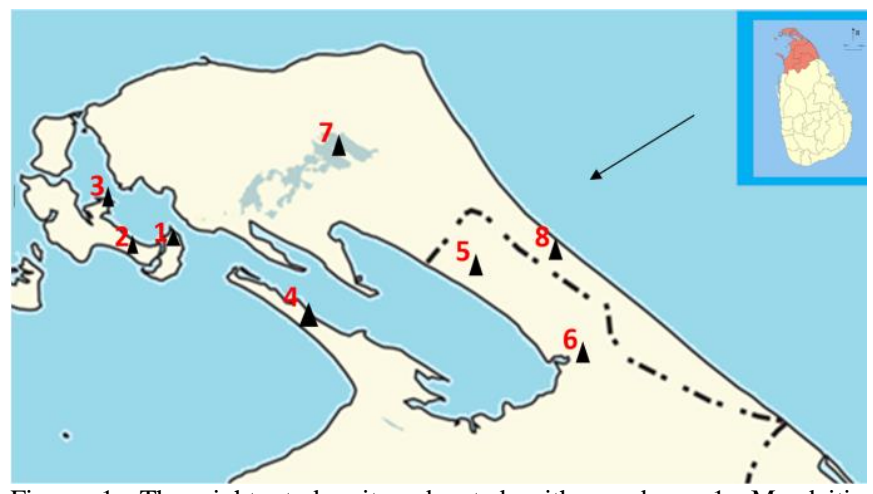

Figure 1: The eight study sites denoted with numbers. 1: Mandaitiv, 2: Mankumban, 3: Kayts, 4: Kavutharimunai, 5: Pallai, 6: Thadduvankoddy, 7: Kapputhu and 8: Nagarkovil.

\section{Data Analysis}

Diversity indices such as Shannon Diversity Index $(\mathrm{H})$, Pielou Index (J), Margalef's Richness Index and Berger-Parker Dominance Index were used to compare the diversity and abundance of waterbirds in eight study sites (Magurran, 2004). The percentage of occurrence was compared for families of waterbirds recorded. Abundance of waterbird families were compared by creating the dendrogram with the help of Minitab 17 to find out similarities among the study sites. Twoway ANOVA was also calculated by using SPSS 14 to find out the variations in the diversity and abundance of birds with regards to the study sites.

\section{RESULTS AND DISCUSSION}

Current study recorded a total of 65 waterbird species belonging to 18 families (Figure 2). Of these, 27 species were migrants, 1 was mainly migrant with resident population, another 5 were mainly residents with migrant population, 2 were mainly residents with doubtful migrant status, and rest of the 30 were residents. Among them, 12 waterbird species were recorded in all eight sites (Table 3). The highest species richness was found in Kapputhu (57) and the lowest in Kavutharimunai (26). 116 species of waterbirds belonging to 23 families were recorded in the Jaffna, Kilinochchi, Mullaitivu and in Mannar in the northern region of Sri Lanka in a previous study (Wijesundara et al., 2017).

\section{A. Species richness, diversity and evenness}

Among the eight locations, the highest measure of species richness was found in Kapputhu (57) (Table 1). However, the Shannon-Wiener diversity index was comparatively lower (2.92) in Kapputhu compared to Mandaitivu (3.22) due to the domination of two families Phoenicopteridae (percentage of occurrence $26.46 \%$ ) and Anatidae (20.96\%) in Kapputhu. Berger Parker dominance index was higher in Kapputhu (0.26) compared to Mandaitivu (0.16).

The highest Shannon diversity (3.22) and even distribution (0.84) and the lowest Berger Parker dominance (0.16) were found in the waterbird assemblages in Mandaitivu. This may be due to the presence of rich microhabitats such as mangroves, marshlands, open water pools, wet and dry mudflats that provide habitats for a range of waterbirds. As far as Mandaitivu, Mankumban and Kayts were concerned, migrant ducks (Family Anatidae), showed high abundance (38.46\%, 37.03\% and $38.09 \%$ respectively).

The lowest species richness and the lowest Shannon diversity and evenness were found in Kavutharimunai. The intertidal area and shallow waters of this location dominated by a large congregation of shorebirds belong to family Scolopacidae $(54.79 \%)$ and seabirds of families, Sternidae $(15.58 \%)$ and Laridae $(11.12 \%)$ for feeding and resting which may have resulted the lowest species richness and diversity measures in Kavutharimunai.

Based on the abundance, Phoenicopteridae and Anatidae were the highly dominated waterbird families in Thadduvankoddy (Figure 02). Families Scolopacidae and Phalacrocoracidae were the dominant families in the seashore near the Pallai wind farm and Nagarkovil respectively. The deep water (>1 m) and dense mangrove vegetation of Nagarkovil provided suitable feeding and roosting for diving birds of Family Phalacrocoracidae. As such these observations showed the ecological value of these areas in the development of avitourism in the northern region of Sri Lanka.

A significant site effect (Table 2) indicated that waterbird families were different among the eight locations. Habitat heterogeneity, availability of water and food and disturbances

Table 1: Comparison of species richness, diversity, evenness, richness and dominance indices in eight study sites.

\begin{tabular}{lcccccccc}
\hline \multicolumn{1}{c}{ Variable } & $\mathbf{1}$ & $\mathbf{2}$ & $\mathbf{3}$ & $\mathbf{4}$ & $\mathbf{5}$ & $\mathbf{6}$ & $\mathbf{7}$ & $\mathbf{8}$ \\
\hline Species Richness & 47 & 49 & 41 & 26 & 37 & 50 & 57 & 41 \\
Shannon - Wiener (H) & 3.22 & 2.89 & 2.71 & 1.92 & 2.57 & 2.46 & 2.92 & 2.57 \\
Pielou Index (J) & 0.84 & 0.74 & 0.73 & 0.58 & 0.71 & 0.62 & 0.72 & 0.68 \\
Margalef's Species Richness index & 6.50 & 5.56 & 5.13 & 3.42 & 5.48 & 5.64 & 6.30 & 5.36 \\
Berger Parker Dominance Index & 0.16 & 0.21 & 0.27 & 0.53 & 0.35 & 0.32 & 0.26 & 0.27 \\
\hline
\end{tabular}

1: Mandaitiv, 2: Mankumban, 3: Kayts, 4: Kavutharimunai, 5: Pallai, 6: Thadduvankoddy, 7: Kapputhu and 8: Nagarkovil. 


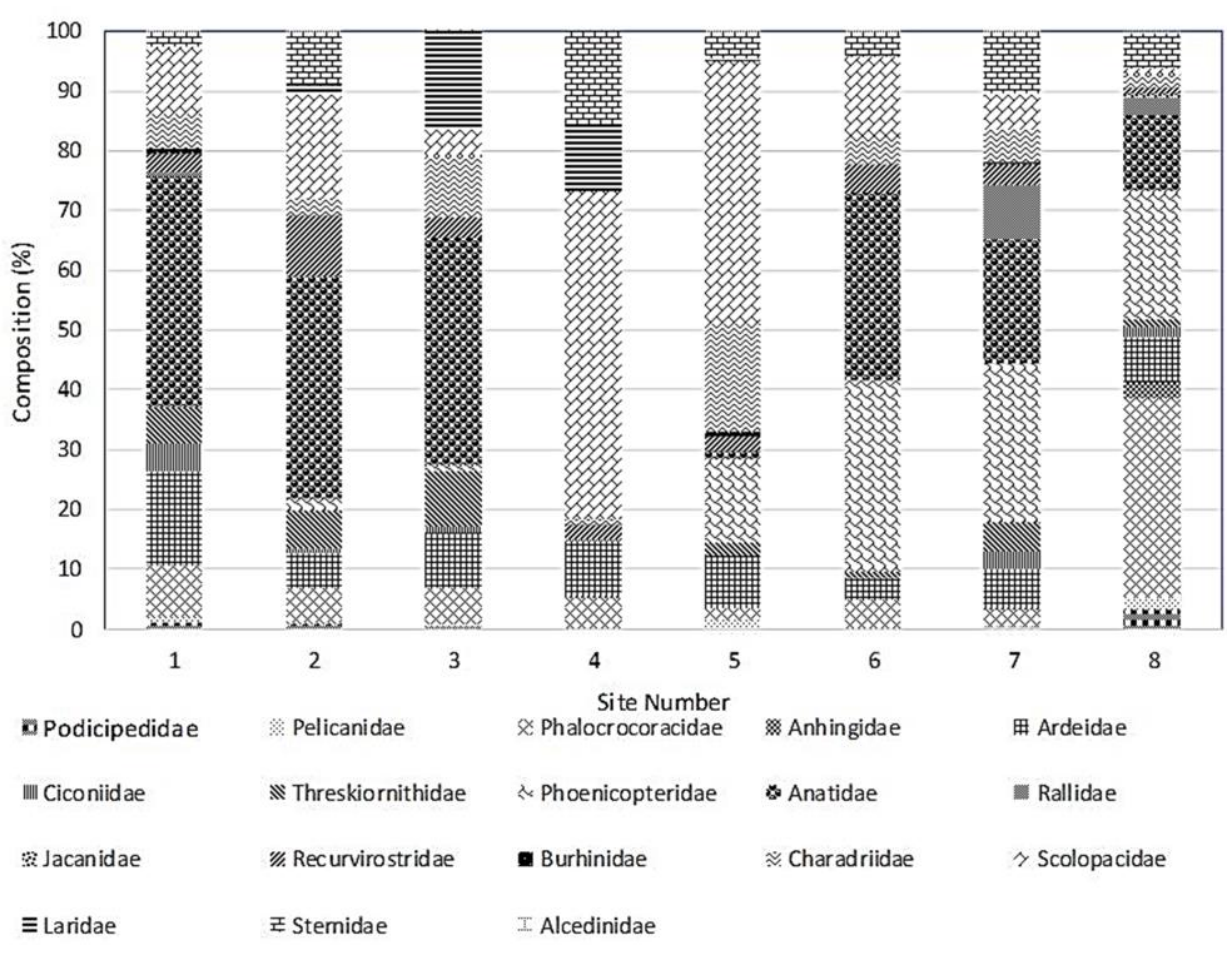

Figure 2: Composition of waterbird families (\%) in eight locations; 1: Mandaitivu, 2: Mankumban, 3: Kayts, 4: Kavutharimunai, 5: Pallai, 6: Thadduvankoddy, 7: Kapputhu and 8: Nagarkovil.

may cause an effect in spatial variation in waterbird families in eight locations.

The dendrogram (Figure 3) showed three major clusters. The study sites namely Mandaitivu (1), Pallai (5), Kavutharimunai (4), Kayts (3), Nagarkovil (8) were closely related in terms of abundance of waterbirds compared to Mankumban (2), Thadduvankoddy (6) and Kapputhu (7). Kavutharimunai (Site 4) and Pallai (5) were clustered together because both were dominated by Scolopacidae. Mankumban (2), Thadduvankoddy (6) were clustered together. This may be due to the similarity in percentage in the most dominant waterbird family, Anatidae. Kapputhu (7) was separated from other sites. The highest species richness and high Shannon diversity Index next to Mandaitivu were recorded in Kapputhu. Therefore Kapputhu was found to be the most suitable area amongst all the sites to observe numerically abundant waterbird species with high species richness.

Table 2: The result of the two-way ANOVA (Tests of Between-Subject Effects) for the two variables (month and site) and their interaction. (Statistically significance levels in terms of abundance of waterbird species are given)

\begin{tabular}{lccc}
\hline \multicolumn{1}{c}{ Source } & $\begin{array}{c}\text { Degrees of } \\
\text { freedom }\end{array}$ & F & $\begin{array}{c}\text { Significance } \\
(<\mathbf{0 . 0 5})\end{array}$ \\
\hline Corrected Model & 47 & 1.66 & 0.02 \\
Intercept & 1 & 82.56 & 0 \\
Month & 5 & 1.11 & 0.36 \\
Site & 7 & 6.32 & 0 \\
Interaction (Month $\times$ Site) & 35 & 0.80 & 0.76 \\
\hline
\end{tabular}

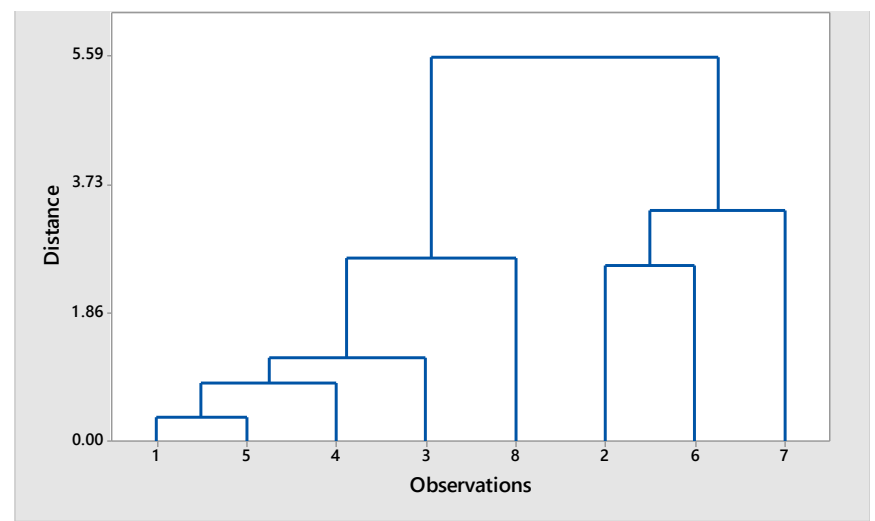

Figure 3: Dendrogram showing the relationship among the study sites based on the abundance of waterbirds (1: Mandaitivu, 2: Mankumban, 3: Kayts, 4: Kavutharimunai, 5: Pallai, 6: Thadduvankoddy, 7: Kapputhu and 8: Nagarkovil)

\section{B. Threatened species in Sri Lanka}

Spot-billed Duck (Anas poecilorhyncha) were recorded in Mandaitivu, Mankumban, Kayts, and Kapputhu (Figure 4). They were most abundant in Mankumban. They are considered as critically endangered species in Sri Lanka (Weerakoon, and Gunawardena, 2012). Food availability, water level and habitat structure of mangroves and saltmarsh ecosystem in the study area might provide suitable habitat for them, suggesting the importance of conservation of these habitats. 


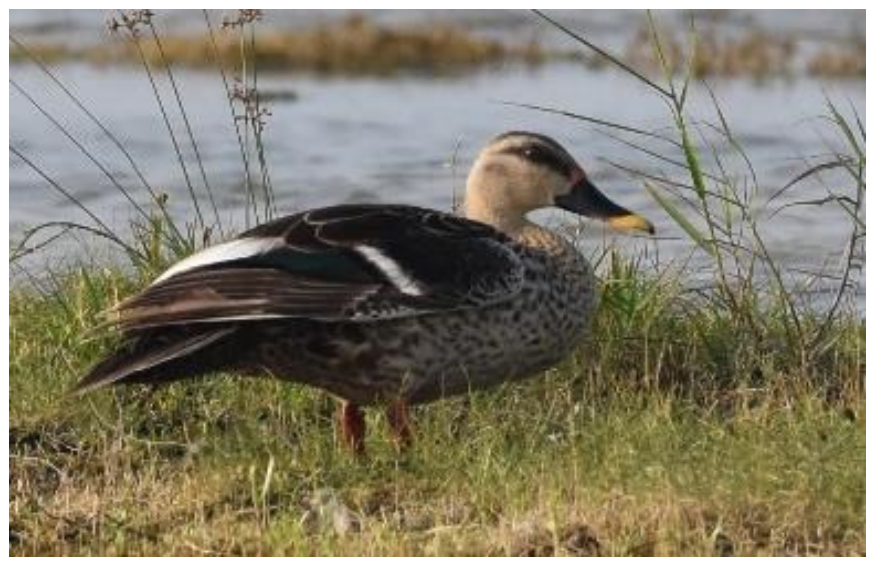

Figure 4: Spot-billed duck (Anas poecilorhyncha) in Kayts (Photograph by Gajavathany Kandasamy).

\section{CONCLUSION}

Mandaitivu, Mankumban, Kayts, Thadduvankoddy, Kapputhu and Nagarkovil were excellent habitats to observe waterbird families of Anatidae and Phoenicopteridae. Kavutharimunai is suitable to observe families Scolopacidae, Laridae and sternidae by ferry. These are potential areas for avitourism in the northern region of Sri Lanka. Moreover, Kapputhu and Nagarkovil are suitable to observe both feeding and roosting of waterbirds. The current study recognizes these sites as important habitats for protection of waterbirds and for the development of avitourism in the northern region.

\section{Future Directions AND ReSEarch Priorities}

Avitourism is an emerging sub-sector of the nature-based tourism industry (Steven et al., 2015). Bird related studies were rare in the northern region of Sri Lanka nearly for three decades due to the armed conflict. In recent times most of the published researches focused on diversity and abundance of waterbirds in the northern region, Sri Lanka. Studies have identified considerable number of birding areas with a high avitourism potential in the northern region of Sri Lanka (Kandasamy et al., 2016; Kandasamy et al, 2017a; Kandasamy et al, 2017b; Kandasamy et al, 2017c; Kandasamy et al, 2017d; Kandasamy et al, 2018; Rajkumar and Wijesundara, 2014; Wijesundara et al., 2015; Wijesundara et al., 2017;
Rajkumar and Wijesundara, 2015a; Rajkumar and Wijesundara, 2015b; Wijesundara et al., 2015; Rajkumar and Wijesundara, 2017; Wijesundara and Rajkumar, 2016; Wijesundara et al., 2016; Wijesundara and Rajkumar, 2017; Wijesundara et al., 2018).

In addition to identify the potential locations in the northern region of Sri Lanka, collaborations are needed between the natural and social science community to investigate the attitudes of currently visiting avitourists and the local public towards birds, bird habitats and bird conservation for the development of sustainable avitourism in the northern region of Sri Lanka. A more detailed research is needed to assess specific bird groups and locations in the northern region, Sri Lanka that can attract avitourists. This kind of research will direct to find opportunities for the development of avitourism and to find which sites may be vulnerable to the potential negative impacts of the industry.

The ecology of waterbirds is poorly known in the northern region of Sri Lanka. In the present study 18 waterbird families were recorded in the region. Each family has different foraging strategies for their survival. During migratory seasons, foraging is the most important activity for shorebirds, as it allows them to survive and ensures their safe arrival at the breeding ground (Norazlimi and Ramli, 2015). Moreover, different locations rich in different microhabitats support various waterbird families. A good knowledge of their habitat requirements is essential for the management and conservation of wetlands for the protection of waterbirds.

Foraging strategies play important roles in the habitat use of shorebirds at stopover sites and wintering grounds. Shorebirds with different foraging strategies select different habitats and use different food resources, and this may effectively avoid interspecific competition (Jing et al., 2007). As such studies on abundance and availability of food in each habitat and habitat usage patterns of waterbirds are important in these areas. Therefore studies on feeding ecology and habitat use remain high priorities for the waterbird conservation of the northern region, Sri Lanka.

Table 3: Status of waterbird species in the eight study sites

\begin{tabular}{|c|c|c|c|c|c|c|}
\hline & Family name & Common Name & Scientific Name & Resident / Migrant & NCS & GCS \\
\hline 1 & Podicipedidae & Little Grebe & Tachybaptus ruficollis & $\mathrm{R}$ & LC & $\mathrm{LC}$ \\
\hline 2 & Pelecanidae & Spot-billed Pelican & Pelecanus philippensis & $\mathrm{R}$ & $\mathrm{LC}$ & NT \\
\hline 3 & Phalacrocoracidae & Indian Cormorant & Phalacrocorax fuscicollis & $\mathrm{R}$ & $\mathrm{LC}$ & $\mathrm{LC}$ \\
\hline 4 & Phalacrocoracidae & Little Cormorant & Phalacrocorax niger & $\mathrm{R}$ & $\mathrm{LC}$ & $\mathrm{LC}$ \\
\hline 5 & Anhingidae & Oriental Darter & Anhinga melanogaster & Uncommon R & $\mathrm{LC}$ & NT \\
\hline 6 & Ardeidae & Grey Heron & Ardea cinerea & $\mathrm{R}$ & $\mathrm{LC}$ & $\mathrm{LC}$ \\
\hline 7 & Ardeidae & Purple Heron & Ardea purpurea & $\mathrm{R}$ & $\mathrm{LC}$ & $\mathrm{LC}$ \\
\hline 8 & Ardeidae & Great Egret & Egretta alba & $\mathrm{R}$ & $\mathrm{LC}$ & $\mathrm{LC}$ \\
\hline 9 & Ardeidae & Intermediate Egret & Ardea intermedia & $\mathrm{R}$ & $\mathrm{LC}$ & $\mathrm{LC}$ \\
\hline 10 & Ardeidae & Little Egret & Egretta garzetta & $\mathrm{R}$ & LC & $\mathrm{LC}$ \\
\hline 11 & Ardeidae & Cattle Egret & Ardea ibis & R.M? & $\mathrm{LC}$ & $\mathrm{LC}$ \\
\hline 12 & Ardeidae & Indian Pond Heron & Ardeola grayii & $\mathrm{R}$ & $\mathrm{LC}$ & $\mathrm{LC}$ \\
\hline 13 & Ardeidae & Striated Heron & Butorides striatus & $\mathrm{R}$ & $\mathrm{LC}$ & $\mathrm{LC}$ \\
\hline
\end{tabular}


Table 3: (continued)

\begin{tabular}{|c|c|c|c|c|c|c|}
\hline & Family name & Common Name & Scientific Name & Resident / Migrant & NCS & GCS \\
\hline 14 & Ardeidae & Yellow Bittern & Ixobrychus sinensis & $\mathrm{R}, \mathrm{M}$ & NT & $\mathrm{LC}$ \\
\hline 15 & Ciconiidae & Painted Stork & Mycteria leucocephala & $\mathrm{R}$ & LC & NT \\
\hline 16 & Ciconiidae & Asian Openbill & Anastomus oscitans & $\mathrm{R}$ & LC & $\mathrm{LC}$ \\
\hline 17 & Threskiornithidae & Black-headed Ibis & Threskiornis melanocephalus & $\mathrm{R}$ & LC & NT \\
\hline 18 & Threskiornithidae & Glossy Ibis & Plegadis falcinellus & M & & $\mathrm{LC}$ \\
\hline 19 & Threskiornithidae & Eurasian Spoonbill & Platalea leucorodia & $\mathrm{R}$ & LC & $\mathrm{LC}$ \\
\hline 20 & Phoenicopteridae & Greater Flamingo & Phoenicopterus roseus & M & & $\mathrm{LC}$ \\
\hline 21 & Anatidae & Lesser Whistling Teal & Dendrocygna javanica & $\mathrm{R}$ & LC & $\mathrm{LC}$ \\
\hline 22 & Anatidae & Eurasian Wigeon & Anas penelope & M & & $\mathrm{LC}$ \\
\hline 23 & Anatidae & Northern Shoveller & Anas clypeata & M & & $\mathrm{LC}$ \\
\hline 24 & Anatidae & Northern Pintail & Anas acuta & M & & $\mathrm{LC}$ \\
\hline 25 & Anatidae & Garganey & Anas querquedula & M & & $\mathrm{LC}$ \\
\hline 26 & Anatidae & Common Teal & Anas crecca & M & & $\mathrm{LC}$ \\
\hline 27 & Anatidae & Spot-billed Duck & Anas poecilorhyncha & $\mathrm{R}, \mathrm{M}$ ? & $\mathrm{CR}$ & $\mathrm{LC}$ \\
\hline 28 & Rallidae & White-breasted Waterhen & Amaurornis phoenicurus & $\mathrm{R}$ & LC & $\mathrm{LC}$ \\
\hline 29 & Rallidae & Purple Swamphen & Porphyrio porphyrio & $\mathrm{R}$ & LC & $\mathrm{LC}$ \\
\hline 30 & Rallidae & Common coot & Fulica atra & $\mathrm{R}$ & $\mathrm{LC}$ & $\mathrm{LC}$ \\
\hline 31 & Rallidae & Common Moorhen & Gallinula chloropus & $\mathrm{R}$ & LC & $\mathrm{LC}$ \\
\hline 32 & Jacanidae & Pheasant-tailed Jacana & Hydrophasianus chirurgus & $\mathrm{R}$ & $\mathrm{LC}$ & $\mathrm{LC}$ \\
\hline 33 & Recurvirostridae & Black-winged Stilt & Himantopus himantopus & $\mathrm{R}, \mathrm{M}$ & LC & $\mathrm{LC}$ \\
\hline 34 & Burhinidae & Great Thick-knee & Esacus recurvirostris & $\mathrm{R}$ & LC & $\mathrm{LC}$ \\
\hline 35 & Charadriidae & Yellow-wattled Lapwing & Vanellus malabaricus & Uncommon $\mathrm{R}$ & LC & $\mathrm{LC}$ \\
\hline 36 & Charadriidae & Red-wattled Lapwing & Vanellus indicus & $\mathrm{R}$ & LC & $\mathrm{LC}$ \\
\hline 37 & Charadriidae & Asiatic Golden Plover & Pluvialis fulva & M & & $\mathrm{LC}$ \\
\hline 38 & Charadriidae & Common Ringed Plover & Charadrius hiaticula & M & & $\mathrm{LC}$ \\
\hline 39 & Charadriidae & Little Ringed Plover & Charadrius dubius & $\mathrm{R}, \mathrm{M}$ & VU & $\mathrm{LC}$ \\
\hline 40 & Charadriidae & Kentish Plover & Charadrius alexandrinus & $\mathrm{R}, \mathrm{M}$ & VU & $\mathrm{LC}$ \\
\hline 41 & Charadriidae & Monglian Plover & Charadrius mongolus & M & & $\mathrm{LC}$ \\
\hline 42 & Scolopacidae & Black-tailed Godwit & Limosa limosa & M & & NT \\
\hline 43 & Scolopacidae & Whimbrel & Numenius phaeopus & M & & $\mathrm{LC}$ \\
\hline 44 & Scolopacidae & Eurasian Curlew & Numenius arquata & M & & NT \\
\hline 45 & Scolopacidae & Common Redshank & Tringa totanus & M & & $\mathrm{LC}$ \\
\hline 46 & Scolopacidae & Common Greenshank & Tringa nebularia & M & & $\mathrm{LC}$ \\
\hline 47 & Scolopacidae & Green Sandpiper & Tringa ochropus & M & & $\mathrm{LC}$ \\
\hline 48 & Scolopacidae & Marsh Sandpiper & Tringa stagnatilis & M & & $\mathrm{LC}$ \\
\hline 49 & Scolopacidae & Wood Sandpiper & Tringa glareola & M & & $\mathrm{LC}$ \\
\hline 50 & Scolopacidae & Common Sandpiper & Actitis hypoleucos & $\mathrm{M}$ & & $\mathrm{LC}$ \\
\hline 51 & Scolopacidae & Pintail Snipe & Gallinago stenura & M & & $\mathrm{LC}$ \\
\hline 52 & Scolopacidae & Little Stint & Calidris minuta & M & & $\mathrm{LC}$ \\
\hline 53 & Scolopacidae & Curlew Sandpiper & Calidris ferruginea & $\mathrm{M}$ & & NT \\
\hline 54 & Laridae & Great Black-headed Gull & Larus ichthyaetus & M & & $\mathrm{LC}$ \\
\hline 55 & Laridae & Brown-headed Gull & Larus brunnicephalus & M & & $\mathrm{LC}$ \\
\hline 56 & Sternidae & Whiskered Tern & Chlidonias hybridus & M & & $\mathrm{LC}$ \\
\hline 57 & Sternidae & White-winged Tern & Chlidonias leucopterus & M & & $\mathrm{LC}$ \\
\hline 58 & Sternidae & Gull-billed Tern & Sterna nilotica & $\mathrm{M}, \mathrm{R}$ & $\mathrm{CR}$ & $\mathrm{LC}$ \\
\hline 59 & Sternidae & Caspian Tern & Sterna caspia & $\mathrm{R}, \mathrm{M}$ & CR & $\mathrm{LC}$ \\
\hline 60 & Sternidae & Little Tern & Sterna albifrons & $\mathrm{R}$ & VU & $\mathrm{LC}$ \\
\hline 61 & Sternidae & Lesser-Crested Tern & Sterna bengalensis & M & & $\mathrm{LC}$ \\
\hline 62 & Sternidae & Great-crested Tern & Sterna bergii & $\mathrm{R}$ & NT & $\mathrm{LC}$ \\
\hline 63 & Alcedinidae & Pied Kingfisher & Ceryle rudis & $\mathrm{R}$ & $\mathrm{LC}$ & $\mathrm{LC}$ \\
\hline 64 & Alcedinidae & Common Kingfisher & Alcedo atthis & $\mathrm{R}$ & $\mathrm{LC}$ & $\mathrm{LC}$ \\
\hline 65 & Alcedinidae & White-throated Kingfisher & Halcyon smyrnensis & $\mathrm{R}$ & $\mathrm{LC}$ & $\mathrm{LC}$ \\
\hline
\end{tabular}

NCS- National Conservation Status, GCS - Global Conservation Status, CR-Critically Endangered, R - Resident, M - Migrant

$\mathrm{M}, \mathrm{R}$ denotes the main populations being migrant, with minor resident populations.

$\mathrm{R}, \mathrm{M}$ denotes the main populations being resident, with minor migrant populations

$\mathrm{R}, \mathrm{M}$ ? denotes species were mainly residents with doubtful migrant status

Status of waterbirds according to Wijesundara et al., (2017).

E- Endangered, LC - Least Concerned, VU- Vulnerable (Weerakoon and Gunawardena, 2012). 


\section{ACKNOWLEDGEMENTS}

Financial assistance provided by the University Grants Commission (Grant No. UGC/DRIC/PG/2015(iii)/UJA/01) and University Grant (URG/ SEIT/2016/04) were gratefully acknowledged. We thank Mr. A. Sumanapala, Mr. H. Jayasinghe and Miss. N. Mohanachandran for their support during field surveys. We are grateful to Fisheries' Society, Maniththalai, Kavutharimunai for the help rendered in counting birds using their ferry.

\section{REFERENCES}

Grimmett, R. and Inskipp T. (2007). Edn.2. Birds of the Indian Subcontinent. Christopher Helm (Publishers) Ltd., London. $528 \mathrm{pp}$.

Harrison, J, A. (2011). A Field Guide to the Birds of Sri Lanka. Oxford University Press, Oxford. 208 pp.

Hattori, A. and Mae, S. (2001). Habitat use and diversity of waterbirds in a coastal lagoon Lake Biwa, Japan. Ecological Research Vol. 16: 543 - 553.

Jing, K., Zhijun, M., Li, B., Li, J., and Chen, J. (2007) Foraging strategies involved in habitat use of shorebirds at the intertidal area of Chongming_Dongtan, China. Ecological Research, Vol.22: 559-570. DOI 10.1007/s11284-006-0302-7.

Kandasamy G, Wijesundara C, and Sivaruban A. (2016). Comparison of avifaunal diversity in different habitats in the Jaffna Peninsula. Pages 362 in Peradeniya University Research Proceedings, 2016: 362.

Kandasamy G., Weerakoon, D. K., Sivaruban, A., and Jayasiri, H. B (2017a). Spatial variation of waterbirds in eight selected sites in the Northern Province of Sri Lanka, Australasian Ornithology Conference: 47.

Kandasamy G., Weerakoon, D. K., and Sivaruban, A. (2017b). Spatial variation of waterbirds in Pallai and Thadduvankoddy in the Northern Province of Sri Lanka, Third International Conference on Science, Engineering and Environment, SEEUSQ, 2017, Brisbane, Australia: 124-129.

Kandasamy, G., Weerakoon, D. K., Sivaruban, A., and Jayasiri, H. B (2017c). Spatial variation of waterbirds in Mandaitivu and Kavutharimunai in the Northern Province, Sri Lanka. Online page in Student Conference of Conservation Science (SCCS).

Kandasamy, G., Weerakoon, D. K., and Sivaruban, A. (2017d). Spatial variation of waterbirds in Kapputhu and Nagarkovil in the Jaffna Peninsula. Forty Years of Bird Research - Field Ornithology Group of Sri Lanka, FOGSL symposium, Faculty of Science, University of Colombo.

Kandasamy, G., Weerakoon, D. K., Sivaruban, A., and Jayasiri, H. B (2018). Waterbird diversity in Kavutharimunai in the Northern Province of Sri Lanka, National Aquatic Resources and Development Agency (NARA) International Scientific Sessions: 42.
Kotagama, S., Ratnavira, G. (2010). An illustrated guide to the birds of Sri Lanka. Field Ornithology Group of Sri Lanka, Colombo. $382 \mathrm{pp}$

Magurran, A. E. (2004) Measuring Biological Diversity. Blackwell Publishing, Oxford, 256 pp.

Norazlimi, N, A. and Ramli, R. (2015). The Relationships between morphological characteristics and foraging behavior in four selected species of shorebirds and waterbirds utilizing tropical mudflats. The Scientific World Journal, Vol. 2015: 1-7.

Rajkumar P. and Wijesundara C. (2014). Preliminary observations on migratory birds on the Island of Mandaitivu, Jaffna, Sri Lanka. Pages 30-30 in Proceedings of the Peradeniya University. International Research Sessions, Sri Lanka, Vol. 18.

Rajkumar, P., and C. Wijesundara. (2015a). Avifaunal diversity of Thondaimanaru Lagoon and adjacent areas, Jaffna, Sri Lanka as an indicator of water quality. Pages 24-24 in Fourth International Symposium on Water Quality and Human Health. Postgraduate Institute of Science, University of Peradeniya, Peradeniya.

Rajkumar, P., and C. S. Wijesundara. (2015b). Developing bird-based ecotourism in Jaffna: A case study on mangrove habitats on the islands of Mandaitivu and Sirudivu. Pages 311 311 in Peradeniya University International Research Sessions. University of Peradeniya, Peradeniya.

Rajkumar, P., and C. S. Wijesundara. (2017). Diversity and abundance of migratory birds in Sarasalai and Anthanathidal mangroves in Jaffna District, Sri Lanka. Page 8-8 in PGIS Research Congress 2017. University of Peradeniya, Sri Lanka, Postgraduate Institute of Science, University of Peradeniya, Sri Lanka.

Steven, R., Morrison, C., Castley, J. G. (2014). Bird watching and avitourism: A global review of research into its participant markets, distribution and impacts, highlighting future research priorities to inform sustainable avitourism management. Journal of sustainable tourism: 1-39.

Warakagoda D. and Sirivardana U. (2006). Status of waterfowl in Sri Lanka. In: C. Bambaradeniya, (Ed.). The Fauna of Sri Lanka. The World Conservation Union (IUCN), Colombo: 204-215

Wetlands International (2010). Guidance on Waterbird Monitoring Methodology: Field Protocol for Waterbird Counting. Wetlands International, Wagenigen, The Netherlands. 15 pp.

Weerakoon, D, K. and Gunawardena, K. (2012). The Taxonomy and Conservation Status of Birds in Sri Lanka. In: The National Red List 2012 of Sri Lanka; Conservation Status of the Fauna and Flora. Weerakoon, D.K. \& S. Wijesundara Eds., Ministry of Environment, Colombo, Sri Lanka: 114-133.

Wijesundara, C. S, Chathuranga D, Hettiarachchi T, Perera N, Rajkumar P, Wanniarachchi S, and Weerakoon G. (2015). Avifaunal diversity in Vallai and Thondamanaru areas in 
Jaffna: Potential for Ecotourism. Page 302-302 in Proceedings of the Peradeniya University International Research Sessions, vol. 19 .

Wijesundara, C. S., D. Warakogoda, U. Sirivardana, D. Chathuranga, T. Hettiarachchi, N. Perera, P. Rajkumar, S. Wanniarachchi, and G. Weerakoon. (2015). Biogeography of water birds in the northern avifaunal region, Sri Lanka. National Science Foundation, Colombo: 20.

Wijesundara, C., and P. Rajkumar. (2016). Abundance and status of migratory water birds on Mandaitivu and adjacent areas in Jaffna, Sri Lanka. Pages 324-324 in Peradeniya University International Research Sessions. University of Peradeniya, Peradeniya.

Wijesundara, C. S., D. Chathuranga, T. Hettiarachchi, N. Perera, S. Wanniarachchi, and G. Weerakoon. (2016). Population size of the Greater Flamingo in the Jaffna Peninsula, Sri Lanka. Page 80 in Postgraduate Institute of Science Research Congress. Postgraduate Institute of Science, University of Peradeniya.
Wijesundara, C, S., Warakagoda, D., Sirivardana, U., Chathuranga, D., Hettiarachchi, T., Perera,N., Rajkumar, P., Wanniarachchi, S., and Weerakoon, G. (2017). Diversity and conservation of waterbirds in the Northern Avifaunal Region of Sri Lanka. Ceylon Journal of Science 46 (Special Issue): 143-155.

Wijesundara, C. S., and P. Rajkumar. (2017). Nagar Kovil and Mamunai: Important Refuges for Flamingos and Other Waterbirds in the Jaffna Peninsula. Page 441 in Peradeniya University International Research Sessions. University of Peradeniya, Sri Lanka.

Wijesundara, C. S., S. Wanniarachchi, T. Hettiarachchi, S. Galappaththi, A. Weerawardhana, and P. Rajkumar. (2018). Population size and movements of the greater flamingo (Phoenicopterus roseus) in the Jaffna peninsula, Sri Lanka: Results from a long-term study. Ceylon Journal of Science 47:373-378. 
